\title{
Reaching Souls, Liberating Lands: Cross-cultural Evangelical Missions and Bolsonaro's Government
}

\author{
Artionka Capiberibe ${ }^{1}$ \\ https://orcid.org/0000-0001-7031-2067 \\ ${ }^{1}$ Universidade Estadual de Campinas, Campinas/SP, Brazil
}

This article examines the activities of cross-cultural evangelical missions among indigenous peoples in Brazil and explores how these activities fit into the policies of Jair Bolsonaro's government. The aim is to show how these missions relate to three federal government policies that are currently threatening the existence of indigenous peoples - policies that are expressed in the moral, anti-environmental, and national security agendas. This article argues that the element connecting these different sets of interests is a notion of individual freedom that directly opposes the idea of collective rights and, therefore, represents an expression of anti-democratic values.

Keywords: Brazil; indigenous peoples; evangelical missions; military; land rights; Bolsonaro government.

http://doi.org/10.1590/1981-3821202100020002

Correspondence: artionka@unicamp.br

This publication is registered under a CC-BY Licence. 
$E^{\prime \prime}$ ven before taking office, Jair Bolsonaro had already expressed the interest in removing indigenous peoples from their constitutionally guaranteed lands, repeatedly saying that "if I take office [as president], there will not be an extra square centimeter for indigenous land" (BOLSONARO, 2020). The culturally-based argument underpinning this political stance is the old and outdated notion of 'integration' into society, treated here as the indigenous peoples' desire to be 'like us'. Hence Bolsonaro's rough question: “why keep Indians on land reserves as if they were animals in zoos?" (WETERMAN, 2018). This argument is coupled with two others. First, an economic argument, which assumes that leaving to indigenous peoples the occupation of portions of the territory that could well be exploited by the mining and agriculture industries is unjustified. Secondly, a geopolitical argument, which is associated with the military paranoia regarding alleged international greed over the Amazon rainforest.

Once in office, the president has been working to turn these arguments into public policy. This is observed on three intertwined fronts. The first - led by minister Damares Alves (from the MMFDH - Ministry of Women, Family, and Human Rights) - attempts to impose a moral agenda that is intolerant to the values and practices such as the indigenous cosmologies and epistemologies - that are deemed unfit according to Christian moral codes. The second front, which involves the deconstruction of socioenvironmental protection policies, is led by the environment minister, Ricardo Salles, and supported by the FUNAI (Nation Indian Foundation), the Brazilian agency responsible for protecting indigenous people, which is currently presided over by a Federal Police Chief. The third front is formed by members of the military who have taken strategic positions in Bolsonaro's government, from where they are implementing policies that are guided by outdated and inappropriate notions like the aforementioned 'integration'. Standing out on this last front is the retired army general Augusto Heleno, who is the current chief minister of the Institutional Security Office. The political activities of the cross-cultural missions - the subject of this article - are linked to these three intertwined fronts, more directly to FUNAI but also to the MMFDH. As we will see, this context promotes a new (old) conservative, anti-democratic order that is based on a specific notion of freedom and is directly threatening the existence of the indigenous peoples. 
In order to make sense of the association between religious missions and an overtly anti-indigenous government policy. I will first identify the core participants in these three intertwined fronts, as well as in the crosscultural missions, exposing their motivations and their activities in the field. I will demonstrate that these missions' practices are aligned with the ideologies of the governments during the military regime in Brazil (1964-1985) - ideologies that are currently re-emerging. Our goal is to reach a deeper understanding of how these missions fit into Bolsonaro's government and what are the political and economic consequences associated with this movement that - although fundamentally religious - has an impact on other domains.

\section{The cross-cultural missionary practice}

Cross-cultural missions are evocative of certain issues associated with the history of Christian missions in Brazil. For centuries, religious orders within the Catholic Church have played a major role in the colonization process by the association of religious conversion with the notion of civilization. In the second half of the 20th century, however, with the Second Vatican Council, the Catholic Church adopted a more critical stance towards this role and has since then sought to make religion more adaptable to indigenous cultures through the theology of inculturation, by which fundamental Christian values - such as love, fraternity, solidarity, and justice - are identified in indigenous cultures (ALMEIDA, 2006, p. 283); at the same time, the Catholic Church adopted a social and political agenda in support of indigenous rights, moving slightly away from a purely salvationist language. Although time passes and agents change, certain practices and meanings persist. As Ronaldo de Almeida (2006) points out, cross-cultural missions in the last decades have been practicing Salvationism, as did the Jesuits during the colonial period.

In short, cross-cultural missions are interdenominational evangelical organizations whose goal is to spread out the Christian doctrine and culture to nonChristian societies. The NTM's (New Tribes Mission) profile by Rubem César Fernandes (1980) provides a general understanding of the motivations behind these missions. According to Fernandes (1980), the NTM originated from a confessional network that was created following the schism in major religious 
denominations in the United States after the civil war, when protestant churches of the North were separated from those of the South. Because the denominations in the North were linked to the country's major universities (Columbia, Princeton, Yale, Harvard, and Chicago), their theological education absorbed elements of the scientific methodology, incorporating the historical exegesis and the philological criticism of the Holy Scriptures, thus resulting in a liberal theology concerned with issues of inequality and poverty (FERNANDES, 1980, p. 140).

The remaining denominations from the schism formed the so-called Bible Belt (a region that includes the South and the Mid-West of the United States), where churches have a conservative view of the Christian dogma and morality, and the Bible is accepted as the source of revelation. As Fernandes (1980) points out, although these churches are made up of those who lost the American civil war, they are part of what Nixon called the "silent majority" (FERNANDES, 1980, p. 142), which proved to be a very strong political force that occasionally emerges and radically changes the directions of that country - as was the case with Donald Trump's election in 2016. Despite changes in the distribution of votes for the 2020 presidential election, this 'silent majority' remains strong and solid, the ultimate beneficiary of the neoliberal attack on the principle of equality that should uphold democracies (BROWN, 2019). These are the churches sustaining the cross-cultural missions in Brazil, where they are mainly interested in indigenous peoples, especially those with little or no contact with society.

The cross-cultural missions' central activity is to translate the Bible, which is taken as the essential element of mediation between God and humanity. More specifically, they translate The Book of Genesis, The Book of Revelation, and the Gospels at the beginning of the New Testament (Matthew, Mark, Luke, and John), where the core of the religious doctrine that guides these missions is found: the eschatological perspective of the world and the notion that life after death could be reached with the Second Coming of Jesus Christ. Yet, for this to occur, they believe they must fulfill the 'Great Commission', which they see as a command in some of the Gospels, particularly in chapter 28, verses 18-20 of Matthew's Gospel. In this chapter, a teleological premise to humanity is asserted, encouraging missionaries to 'reach' all the peoples of the planet, with the understanding that each language corresponds to a people. The term 'to reach' has a profound meaning, as it

$$
\text { (2021) } 15(2) \quad \text { e0003-4/22 }
$$


conveys the sense that not only everybody can receive 'the word of God' from the Bible - a form of access that allows people 'to accept Jesus' as their savior - but also that the end of the world is to be completed with the Second Coming of Jesus - the event that would lead all nations in the planet to be baptized and become followers of Christ.

The translation of the Bible is seen by these missions as a means for understanding something that they preconceive as part of the indigenous cosmologies; the idea of God is thus seen as intrinsic to their cosmologies. This resemblance would be corroborated by the events and characters in the indigenous cosmological universe that are similar to those in the Bible, such as the founding heroes or the creators of the cosmos, as well as the recurrence of stories in a considerable number of indigenous mythologies that resemble those in the Bible - such as the flood narrative, for instance (CAPIBERIBE, 2007).

Moreover, these theological foundations explain why individual missionaries go to distant corners of the world, deep into the Amazon forest, searching for souls and risking contact with people who, due to a long history of violence by nonindigenous people, may react with hostility in the presence of strangers. Cases of deaths of missionaries in these encounters, however, instead of being a deterrent to the missionary practice, foster the 'ethos' of martyrdom, mirroring stories from the Bible and confirming the mission's importance and righteousness.

These theological foundations also partially explain another facet of these missions, one that is less heroic and more mundane, and that unabashedly leads them, not into the woods, but into political alliances with local governments. In doing so, they cannibalize science by strategically misusing anthropological and linguistic methodologies and conceptualizations, that is, they use them in a technical manner and "under the religious code" (ALMEIDA, 2006, p. 282). This is a pragmatic, tactical, and political appropriation because, as we will further see, it will be used to bypass law restrictions on religious proselytism among indigenous peoples. In fact, the principles of non-intervention and respect for indigenous diversity and selfdetermination are being subverted by these missions, principles that make up the ethics of research within these same scientific fields. The Yanomami shaman Davi Kopenawa's account of the activities of the NTM among his people reveals the violence caused by this subversion: 
The people of Teosi [the missionaries] focused their anger on those who continued to make the xapiri dance despite it all. They kept telling these shamans that they were evil and that their chests were dirty. They called them ignorant. They threatened them: "Stop making your forest spirits dance, it is evil! They are demons whom Teosi [God] has rejected! Do not call them, they belong to Satanasi! [Satan]. [...] These evil words, repeated unceasingly, finally frightened all the shamans, and they no longer dared to drink the yãkoana or even sing during the night. They only asked themselves who this Teosi could be to mistreat them so!" (KOPENAWA and ALBERT, 2013, pp. 188-189).

Because of the theology and the behavioral ethos involved, these crosscultural missions are becoming agents of a depoliticized action, a form of action that is opposite to a democratic political action aimed at some sort of collective social transformation (BROWN, 2019). They have little interest in mundane issues, such as defending the right to land demarcation; on the contrary, their strategic political action focuses on the spiritual and transcendent world. To do so, they resort to a dual identity strategy.

As an example of this pattern of missionary practice, I mention here two of the largest and oldest cross-cultural missions exclusively devoted to the conversion of indigenous peoples, both of American origin: the previously mentioned New Tribes Mission, founded in 1942 and renamed Ethnos $360^{1}$ in 2017, and the SIL (Summer Institute of Linguistics), created in 1934, now called SIL International and, in Portuguese, 'Sociedade Internacional de Linguística'. The latter is divided into two organizations, one of which, the WBT (Wycliffe Bible Translators), is the public missionary face of SIL (BARROS, 2004; STOLL, 1982).

In general ${ }^{2}$, these organizations are established as multinational corporations, with their organizational charts and audited financial statements. Both organizations have a large number of people on the mission field and apply a considerable quantity of resources: SIL is involved in approximately 1,350 active

\footnotetext{
${ }^{1}$ Their name was changed after a decade of pedophilia scandals involving NTM missionaries. The fact that these scandals were poorly handled by the organization suggests that this rebranding may well have been a means to clean up its reputation. Information about the scandals is available at <https://www.nbcnews.com/news/religion/ungodly-abuse-lasting-torment-newtribes-missionary-kids-n967191> and at <https://amazoniareal.com.br/exmissionario-condenado-nos-eua-trabalhou-com-indios-do-acre/>.

${ }^{2}$ The following data are available at <https://www.sil.org/> and <https://ethnos360.org/>.
}

$$
\text { (2021) } 15(2) \quad \text { e0003-6/22 }
$$


language projects that are developed in 104 countries by more than 4,300 employees from 89 different countries, working with thousands of local partners worldwide (data from 2020). Ethnos $360^{\circ}$ comprises 2,500 missionaries from 30 different countries in Africa, Latin America, and the Asia Pacific. Moreover, they also have well-established infrastructure divisions ${ }^{3}$.

From their top leadership positions among cross-cultural missions, these two organizations have been exerting influence on the creation and operation of other organizations, who typically act in connection with local governments, engage in nationwide programs (in some cases), and are vulnerable to political contingencies.

It is worth describing in detail an event that occurred in the late 1970s in Brazil, from which we can see that the coordination between cross-cultural missions and governments is not something restricted to the present and has been following a persistent pattern. After about thirty years of friendly relations for the study of indigenous languages, the interior ministry, to which FUNAI was subordinated at the time, decided not to renew yet another cooperation agreement with SIL, ordering the missionaries to leave the indigenous lands immediately. Among the government's justifications were indirect and veiled accusations that geologists disguised as missionary linguists were secretly prospecting for minerals in the Amazon region. This accusation, however, was never openly stated. Two official reasons were given for the dismissal: first, that the results of the indigenous literacy program carried out by SIL were 'precarious' - an adjective used by the interior minister at the time, Rangel Reis (DIÁRIO DO CONGRESSO NACIONAL, 1978, p. 381); secondly, that Brazilian researchers should be given preference, as was phrased by the president of FUNAI at the time, army general Ismarth Araújo de Oliveira (DIÁRIO DO CONGRESSO NACIONAL, 1978, p. 348). While defending themselves against the accusations of illegal mining activity, SIL revealed that they had also been unfairly accused, in other Latin American countries, of being CIA agents, which may have rather deepened the suspicions of the Brazilian military government ${ }^{4}$.

${ }^{3}$ See <https://www.jaars.org/> and <https://ethnos360aviation.org/>.

${ }^{4}$ All data in this paragraph were extracted from the newspapers 'Folha de São Paulo' (on the 23 November 1977 issue) and 'O Estado de São Paulo' (on the 24 November 1977 issue). This information was also addressed by Stoll (1982). 
At the same time, Rangel Reis was trying to enact a decree for the emancipation of indigenous peoples, putting an end to the regime of state guardianship (covered by Art. 07 of the Statute of the Indian, Law 6001/1973), which determines that, because indigenous people do not have "full civil capacity" (Art. 09 of Law 6001/73), they must be kept under the legal responsibility of the Union. If, on the one hand, guardianship is an inappropriate solution, emancipation - as it was being designed - meant the dissolution of the indigenous identity, a measure that would have an impact on the State's responsibility to guarantee the indigenous population's right to the land that, since the Constitution of 1934, was legally theirs. Given the current context in Brazil, it is noteworthy that, at that time, the proposal to emancipate the indigenous population was justified as a response to the will of the indigenous peoples themselves, who would then be able to fulfill their "desire to be Brazilian citizens with full rights" (RANGEL REIS apud DIÁRIO DO CONGRESSO NACIONAL, 1978, p. 369). These ideas are still being expressed with the same terms by the Brazilian minister general Augusto Heleno whenever he criticizes the demarcation of indigenous lands. The military regime, thus, had based its proposal for emancipation on an idea that evokes freedom, but a type of freedom that can only come at the expense of indigenous identity. I will return to this issue later.

In short, for the military dictatorship, the cooperation agreement with SIL was instrumental to complying with Art. 50 of Law 6001/73, which determines education as the means to assist in the process - deemed inevitable - of integrating the indigenous population into the Brazilian society. And here the idea of emancipation fits in, acting as a harbinger of the integration process. The potential threat to national sovereignty posed by the suspicious activities of the missionaries undermined the relationship between the missionary organizations and the government; however, this case shows that both sides share certain ideas, interests, and practices, all of which have contributed to opposing legally recognized collective social rights. As we will see, this situation persists to this day.

\section{The missions and Bolsonaro's government}

With the transition to democracy in Brazil, public policies for indigenous peoples have undergone important transformations. This transition involved the

$$
\text { (2021) } 15(2) \quad \mathrm{e} 0003-8 / 22
$$


promulgation of a new Constitution in 1988, which, for the first time, had a specific chapter for indigenous peoples - entitled 'Indians' - comprising two articles. The first, Article 231, recognizes indigenous languages, customs, social organization, and traditions, as well as their right to the lands they have traditionally occupied; the second, Article 232, reverses the status of guardianship - and thus also the notion of integration - by giving indigenous peoples the right to defend themselves in court. In addition to the Constitution of 1988, international legal instruments were being created, such as the ILO Convention № 169, ratified by the Brazilian government in 2002, and the United Nations Declaration on the Rights of Indigenous Peoples (UNDRIP) ${ }^{5}$.

The executive branch in Brazil was aware of these developments and progressively incorporated the new legal principles. Highlights in this process were the establishment of the procedures for the demarcation of indigenous land (regulated by decree № 1775/96) and the creation of policies specifically designed for indigenous peoples in voluntary isolation ${ }^{6}$, that is, policies that follow the guidelines of non-contact and remote surveillance (under administrative order № 1900/87). These two sets of policies are currently the most threatened by the combined efforts of the federal government, missionary organizations, and economic interests - particularly those of the agriculture and mining industries.

This threat is associated with the current weakening of barriers for entering indigenous land. In the past, to enter indigenous lands, missionaries had to go through rather tortuous institutional paths, mainly within Congress - where they were already part of the triad known as the 'Bancada do Boi', 'da Bala' e 'da Bíblia' (the Beef, Bullet, and Bible bloc), which aggressively lobbies for the agribusiness, the arms industry, and conservative religious groups. Today, however, the missions' representatives are moving with ease within the federal executive, occupying strategic positions, and assisting in the elaboration of non-statutory measures ${ }^{7}$ that threaten the achievements made so far by the indigenous movement - who

\footnotetext{
${ }^{5}$ For details about the public policies and conflicts regarding indigenous rights during the transition to democracy, cf. BONILLA and CAPIBERIBE (2021, in press).

${ }^{6}$ They are named that way because it is understood that they want to be left isolated.

7Their tactics were exposed by a leaked recording of the ministerial meeting held on 03 May 2020, in which the environment minister, Ricardo Salles, used an expression ("to pass the cattle") that suggested taking advantage of media distraction due to the COVID-19 pandemic to change norms via decrees - and soften environmental protection laws.
} 
are thus questioning these measures. I will describe some illustrative cases of missionary political action within Bolsonaro's government to give a sense of the missionary 'modus operandi', indicating who are the key players and what are the controversies involved.

As soon as Bolsonaro took office, the government made its first move against indigenous peoples and in favor of the missions, as it tried to displace FUNAI from the MJSP (Ministry of Justice and Public Security) and split it between the MAPA (Ministry of Agriculture, Livestock, and Supply) and the MMFDH. With this move, the demarcation of indigenous lands would be included in the rural land regularization umbrella - together with the agrarian reform and the 'quilombola' lands - and under the responsibility of the federal deputy and minister Tereza Cristina da Costa (from the political party DEM-MS), who is part of the 'Bancada do Boi' (Beef bloc) in Congress. Those agencies in charge of social rights, on the other hand, would be absorbed by the MMFDH; as previously mentioned, the MMFDH is led by minister Damares Alves, who, in turn, is linked to the 'Bancada da Bíblia' (Bible bloc) in Congress $^{8}$. Because of pressures from the indigenous movement, this specific article of the Provisional Measure № 870/20199 was first overturned by Congress and later by the STF - the Brazilian supreme court - preventing the government from reinstating the article in Provisional Measure № $886^{10}$.

In what concerns the strategy of infiltrating agents in the State, in addition to the appointment of Damares Alves (founder of the cross-cultural mission called 'ATINI Voz Pela Vida'), the appointment of Pastor Ricardo Lopes Dias - whose profile perfectly fits the dual science/religion identity - stands out. With two bachelor's degrees in theology (from the 'Faculdade Teológica Sul Americana') and anthropology (from the 'Universidade Federal do Amazonas'), a master's degree in social sciences (from the 'Universidade Federal de São Paulo'), and a doctoral degree in human and social sciences (from the 'Universidade Federal do ABC'), Dias has also worked for the New Tribes Mission in Brazil (MNTB, in the Portuguese abbreviation) for ten years as a missionary among the Matsés people in the Javari

\footnotetext{
${ }^{8}$ Alves worked as a congressional aide for 20 years, actively supporting conservative religious guidelines.

9This Provisional Measure was later converted as Law 13,844 /2019.

${ }^{10}$ Information available at <http://www.stf.jus.br/portal/cms/verNoticiaDetalhe.asp?idConteudo=414818>.
}

$$
\text { (2021) } 15(2) \quad \text { : } \quad \text { e0003-10/22 }
$$


Valley, a region with the largest concentration of indigenous peoples in voluntary isolation on the planet (RICARDO and GONGORA, 2019). Because of Dias' background, he was appointed to the position of CGIIRC (General Coordinator of Isolated and Recently Contacted Indians), a sensitive area within FUNAI that is responsible for watching over those indigenous peoples that are considered by cross-cultural missions as the 'brown gold mine'- not by chance, 'Brown Gold' is the name of the old NTM official magazine.

Dias' dual identity, however, eventually led to a judicial challenge against his appointment. The MPF - the Brazilian federal prosecution office - filed an ACP (Public Civil Action) ${ }^{11}$ requesting the invalidation of two administrative orders: the first - № 151, issued on 03 February 2020 by the MJSP - enabled Dias' appointment; the second - № 167, issued on 29 January 2020 by the president of FUNAI - changed FUNAI's internal rules so that leadership positions in the agency would no longer be reserved to civil servants of its permanent staff, thus opening the way for Dias' appointment. According to the MPF, Dias' connection to the MNTB represented a conflict of interest - a claim that is supported by information on MNTB's activities among indigenous peoples. MNTB Missionaries had contacted indigenous peoples that are isolated or considered to be 'of recent contact', resulting, in many cases, in a series of deaths by diseases against which they have no immunity - the cases of the Zoé and Yanomami peoples are the most dramatic. The ACP also warns of the risks associated with the facilitated access to data providing the identification and location of isolated peoples. To prove that Dias has a missionary profile, the ACP relied on excerpts from his master's thesis, in which he describes the evangelization of the Matsés, carried out from 1997 to 2007. Dias' appointment was temporarily suspended with an injunction by the TRF-1 (Regional Federal Court of the 1o Region); however, the president of the STJ (Superior Court of Justice, the highest Brazilian court for non-constitutional matters), João Otávio de Noronha, later revoked the injunction, sustaining that Dias' religious profile had not been proven and that he was thus eligible for the position.

Before this decision, ANAJURE (National Association of Evangelical Jurists) and the FPMLRRAH (Mixed Parliamentary Front for Religious Freedom, Refugees

${ }^{11}$ Civil Inquiry № 1.16.000.000332/2020-21, available at <http://www.mpf.mp.br/df/sala de-imprensa/docs/acp-coordenador-funai-1>. 
and Humanitarian Aid) - which operates within Congress - released a public statement supporting Dias' appointment, accusing NGOs and the media of promoting a smear campaign against the 'good reputation of the researcher', and denouncing the MPF's 'veiled religious discrimination'. The statement also alleged that Dias had been disconnected from field activities in the last ten years, thus suggesting that he was no longer engaged in missionary activity. Dias himself had given this same information in his defense in the few statements he gave to the media; however, this is far from the truth. Despite being away from indigenous territories, he was still significantly involved with missionary activity - recognized by his peers - linked to the First Baptist Church of GuaianasesSP, which was founded by him in $2013^{12}$.

The statement's underlying argument was that the right to religious freedom was being curtailed; it proceeds with mentions of the Universal Declaration of Human Rights, the Brazilian Constitution of 1988, the International Covenant on Civil and Political Rights of 1966, and the San Jose Pact of 1969. The intention was to prove that Dias had not only the right to his religious creed but the right to publicly profess it. I transcribe here an excerpt that reveals where this statement stands:
[...] there is no national or international document that would intrinsically restrict the expression of missionary religiosity in indigenous areas under the label of culture protection.
To forbid the presence of a missionary in such spaces, without evidence of actual on-site damage, is to reduce religious plurality, is to accuse without evidence and make a prior judgment based on preconceived ideas and stereotypes [...] $]^{13}$ (ANAJURE, 2020).

In this statement, the notions of freedom and religious 'plurality' surpass the indigenous right to self-determination and contradict the ideas of pluriethnicity and multiculturality (DUPRAT, 2007), both of which being the legal basis for this very same right. Moreover, the statement's argument goes against the indigenous people's right to ontological multiplicity, a notion that brings together the different ways of living and being, allowing for non-human people - such as the Enchanted

\footnotetext{
${ }^{12} \mathrm{An}$ article about this case is available at <https://oglobo.globo.com/brasil/coordenador-de-indiosisolados-da-funai-omite-atuacao-em-projeto-missionario-de -evangelizacao-24385866>.

${ }^{13}$ Highlights in bold are from the original text; emphasis in italics are mine.
}

$$
\text { (2021) } 15(2) \quad \text { e0003-12/22 }
$$


Beings who have a relationship with the Tupinambá of Olivença people, for instance - to be considered subjects with rights (cf. BEZERRA, 2019). Within this framework, which recognizes the epistemic-ontological difference, collective rights are prioritized over the notions of individual rights and private property - these last two elements being important to the sense of freedom that is under dispute.

Once he took office, Dias spoke little about the controversy of his appointment but gave an official interview to the FUNAI website, in which he, instead of clarifying doubts about his impartiality, defended himself by appealing to the right to religious freedom in a secular state, citing the Brazilian Constitution and the Universal Declaration of Human Rights ${ }^{14}$. Although it is undeniable that the right to religious freedom should be protected, when it comes to fundamentalist missionaries and indigenous peoples, the inevitable question is: how far should this right go?

Throughout his time as coordinator of the division of isolated Indians (from March to November 2020), Dias faced a series of complaints that seem to corroborate the arguments against him taking office that were presented by the MPF, the indigenous movement, and the Brazilian Association of Anthropology ${ }^{15}$; these complaints also revealed how deteriorated the sector's policies had become. The complaints ranged from negligence and government takeover by partisan interest to misuse of public resources. The allegations of negligence refer to the growing pressure on isolated peoples due to increased invasions, deforestation, and fires around their lands ${ }^{16}$. Complaints of moral harassment have also been filed, especially regarding civil servants at FUNAI's Ethno-environmental Protection Bases who are directly involved in monitoring the

\footnotetext{
${ }^{14}$ Available at <http://www.funai.gov.br/index.php/comunicacao/noticias/6281entrevista-especial-ricardo-lopes-dias $>$.

${ }^{15} \mathrm{Cf}$. public statements at <https://apiboficial.org/2020/01/31/nota-de-repudiocontr-a-nomeacao-de-missionario-da-mntb-para-the-isolated-sector-in-funai/ $>$ and at <http://www.portal.abant.org.br/2020/02/03/nota-de-denuncia-about-the-risk-of-imminentgenocide-and-ethnocide-of-isolated-indigenous-peoples-in-Brazil />.

16The tragic death of the 'sertanista' (indigenous expert) Rieli Franciscato, in September 2020, is emblematic. He was struck by an arrow when approaching a group of the indigenous people known as 'isolated of Cautário'. This people is under the pressure of poachers and gold miners who of ten invade the territories where they circulate. Article available at <https://noticias.uol.com.br/colunas/rubens-valente/2020/09/10/funai-eindigenistas-tentam-entender-acao-dos- isolated-in-ro.htm>. For more information on the escalation of invasions and deterioration of the environment see: <https://univaja.com/atividadesde-garimpeiros-avancam-no-am-e-ameacam-povos-indigenas-isolados-do-vale-do-javari/> and <https://cimi.org.br/2020/09/incendio-ilha-do-bananal-coloca-em-risco-indigenas- isolated/>.
} 
territories where isolated indigenous people live. The most striking case occurred when Dias, accompanied by an army team, tried to enter the indigenous land 'Vale do Javari' without observing the quarantine that had been imposed due to the COVID-19 pandemic ${ }^{17}$. This protective measure was established by FUNAI's administrative order № 419/202018 - which lays out a series of actions to protect indigenous people - and by an Argument of Non-Compliance with Fundamental Precept № 709, a type of legal action that was filed against the federal government by the APIB (Articulation of Indigenous Peoples of Brazil) ${ }^{19}$.

UNIVAJA (the Union of Indigenous Peoples of Vale do Javari) also denounced Dias' attempt to co-opt leaders by offering them positions within the state, intending to create divisions within the indigenous movement ${ }^{20}$. UNIVAJA had made a similar accusation during Dias' appointment process, when the organization denounced the increased harassment by fundamentalist missionaries in the region, just when the pandemic had begun to spread in Brazil ${ }^{21}$. To protect the indigenous people against this harassment, UNIVAJA filed an ACP (Case № 1000314-60.2020.4.01.3201) to mainly prevent the missionaries from contacting the Korubo, an isolated people who inhabit the surroundings of the Lambança river. UNIVAJA also secured an injunction prohibiting three missionaries - who were specifically named in the legal document - and the MNTB from entering the indigenous land under penalty of fine or expulsion by the police. In his decision, the Federal Judge Fabiano Verli - of the court of Tabatinga - observes that "religious indoctrination, however subjectively important to many people, is not an essential service according to the constitutional ideology, just as secular education is not deemed essential in the context of an epidemic" (JUSTIÇA FEDERAL- SUBSEÇÃO JUDICIÁRIA DE TABATINGA-AM, 2020). Finally, the judge argues that the presence

\footnotetext{
${ }^{17}$ Article available at <https://oglobo.globo.com/brasil/coordenador-da-funai-tentou-quebrarquarentena-indicou-missionarios-para-area-de-indios-isolados- says-chief-of-protection-in-thevalley-of-javari-24657614?utm_source=Twitter\&utmmedium=Social\&utm_campaign=share $>$.

${ }^{18}$ Available at <http://www.planalto.gov.br/ccivil_03/Portaria/PRT/Portaria\%20n\%C2\%BA\%20419-20mjsp-funai.htm>.

${ }^{19}$ Available at <http://www.stf.jus.br/arquivo/cms/noticiaNoticiaStf/anexo/adpf709.pdf>.

${ }^{20}$ Available at <https://univaja.com/2164-2/>.

${ }^{21}$ Available at <https://trabalhoindigenista.org.br/wp-content/uploads/2020/03/ Nota_a\%CC\%80_Imprensa_Univaja_03.03.2020_asse\%CC \%81dio_missiona \%CC\%81 ri orio-1.pdf>. Emphasis added.
} 
of missionaries in indigenous lands during a pandemic cannot be sustained by the arguments of religious freedom or freedom of movement.

This legal action that was brought by civil society is representative of the state's negligence over a topic on which it is legally bound to intervene. This government is, however, determined to violate indigenous rights. Among the various indications of this intention, it is worth mentioning a graduate course 'Anthropology: culture, society, and contemporaneity' - that was proposed and prepared by Dias and Cláudio Badaró (an advisor to the presidency of FUNAI who is in charge of the Studies and Research Monitoring sector). The course was conceived to offer civil servants a training "[...] focused on the human being and his social relations, with an openness to understanding cultural specificities [...]" (FUNAI, Process № 08620.006561/2020-89).

The intentions of the course are commendable at first sight; however, the dual identity of its proponents have raised concerns. While religion and anthropology were interlaced in Dias' background, in Badaró's case, it was anthropology and agribusiness that were brought together. Badaró is notorious for acting in favor of farmers' interests, more specifically, for producing technical reports contradicting those anthropological studies that are used to support requests for the identification of indigenous lands ${ }^{22}$. Also suspicious is the faculty composition, with one-third of the professoriate made up of people directly linked to fundamentalist religious missions, such as ATINI's lawyer, Maíra de Paula Barreto Miranda, who represents ATINI in judicial cases involving an array of controversial issues, including the kidnapping of indigenous children and the misuse of images of indigenous people in a documentary that falsely depicts an infanticide ${ }^{23}$.

Scheduled to start in October 2020, the course did not take place. The Brazilian Association of Anthropology issued a warning against this course ${ }^{24}$, but, most significantly, an investigation by the MPF showed that, according to the

\footnotetext{
${ }^{22}$ Article available at <https:/g1.globo.com/politica/blog/matheus-leitao/post/2019/12/02/assessor-da-funai-jaatuou-contra-criacao-de-novas-terras-indigenas.ghtml .

${ }^{23}$ For more information about this documentary and the consequences of Barreto Miranda's legal strategy of resorting to human rights to advocate for the criminalization of the so-called indigenous infanticide cf. Holanda (2018).

${ }^{24}$ Available at <http://www.portal.abant.org.br/2020/08/24/alerta-da-aba-curso-lato-sensu-emantropologia-proposto-pela-funai/>.
} 
spreadsheet detailing the disbursement for the course, the cost involved would reach, at a time of a pandemic ${ }^{25}$, about $\mathrm{R} \$ 236,000$; Dias and Badaró would be paid around R\$ 70,000 each. Offering the course clearly fits into the 'leitmotiv' of the cross-cultural missions, that is, to use science for shady purposes. In this case, it seems that the intention was to offer some form of training to unqualified staff as to justify their appointments to positions within FUNAI, ultimately supporting the government takeover by partisan interests and, consequently, the missionaries' access to protected indigenous peoples and lands.

As we look at the threats against indigenous people in voluntary isolation, we can clearly see those three intertwined fronts acting together, endangering their autonomous, different ways of being and living, as well as putting their territories at risk. FUNAI's decision to weaken the surveillance over these territories represents an encouragement to their predatory exploitation. Two political actors are known to be in charge of this broad policy designed to subvert state protection of indigenous peoples within Bolsonaro's government: religious organizations and the so-called 'ruralists'26, both of which are supported by a third group of actors, which can be identified as 'security forces', i.e., the military and the federal police.

The picture becomes clearer as we focus exclusively on recent developments within FUNAI. The agency's first president under the Bolsonaro administration was a retired general of indigenous origin named Franklimberg Ribeiro de Freitas, who had been president of FUNAI when Michel Temer was in office - at that time, his appointment was controversial because it evoked the memory of the violations by the civil-military dictatorship when FUNAI was led by the military (KHEL, 2014); one could not have imagined at the time how much worse the situation would get with Bolsonaro's rise to power. During his seven months as head of the indigenous agency in Bolsonaro's government, he supported what he called 'sustainable development' projects, such as - among others - coffee production by the Suruí people, Brazil nut collection among the Cinta Larga, shrimp

\footnotetext{
${ }^{25}$ Article available at <http://mpf.mp.br/pa/sala-de-imprensa/noticias-pa/mpf-pa-abreinvestigacao-sobre-curso-de-missionario-e-ruralista-que-custaria-r-236-mil-a-funai>.

${ }^{26}$ Ruralists are big landowners who defend or represent their interests in the National Congress. The term also designates a predatory disposition towards indigenous lands, 'quilombolas', and Conservation Units. More information available at <http://republicadosruralistas.com.br/>.
} 
production among the Potiguara, and large-scale production of grains by the Paresi. Agribusiness groups from the state of Mato Grosso participated in this last project with the Paresi as financiers, which is controversial within the indigenous movement as the project entails not only a non-communitarian method of land exploitation but also an alliance with an economic sector that acts with violence towards indigenous people (data extracted from a presentation given by Freitas at the Indigenous Lands and National Interests Forum at Unicamp in May 2019).

Although the indigenous movement had its share of concerns regarding Freitas' appointment, what eventually removed him from his position was the 'Bancada do Boi' (Beef bloc) in Congress. Freitas's removal was sponsored by the agribusiness, who was unhappy with his soft model of integration to the national society. The person behind this move is Luiz Antonio Nabhan Garcia, a former president of the UDR (Rural Democratic Union), a radical opponent of the agrarian reform, advocate for rural landowners who defend the right to carry arms, the main operator of the policy for the expansion of the 'agricultural frontier' into the Amazon and indigenous lands and current Special Secretary for Land Affairs (SEAF) within MAPA (Ministry of Agriculture, Livestock and Supply) ${ }^{27}$. Garcia appointed Federal Police Chief Marcelo Augusto Xavier da Silva as president of FUNAI. Since he took office, Silva has disrupted the agency's daily operation by replacing those people in leading positions, halting demarcation processes but also leaving the indigenous peoples with almost no assistance, simply because posts are being left unoccupied. It is noteworthy that the agency has been split between the armed forces and the federal police: three out of the four main FUNAI divisions are run by federal police officers, and the fourth division - the Indian Museum - is run by a retired military officer. Moreover, an informal survey with civil servants - who asked not to be identified - showed that at least 19 out of the 39 FUNAI regional coordination offices are now occupied by military personnel 28 .

Lastly, we focus on minister Damares Alves, perhaps the real connection between the religious and ruralist groups. Two recent stories point in that

\footnotetext{
${ }^{27}$ Garcia's profile is available at <https://apublica.org/2019/11/o-todo-poderoso-nabhan/> .

${ }^{28} \mathrm{~T}$ o get a sense of the growing presence of military personnel in 'cargos comissionados' (a political appointment to a government position) within the Bolsonaro government see: <https://preview.flourish.studio/5202872/T2tMbc_otm_djTbBa5TjnxQZeGuOssq8WLnbmc8pYL 764Sti6FBP6nHeyHEnDT6q/>.
} 
direction. The first involves a donation made by the company Marfrig - one of the largest agribusiness companies in the country - to the health ministry for acquiring rapid tests for SARS-CoV2. The government redirected this money to the 'Pátria Voluntária' program - which is run by the first lady, Michelle Bolsonaro - and, with Alves acting as an intermediary, transferred part of this donation - without a call for competition - to two evangelical missions and to the Brazilian Cross-cultural Missions Association (AMTB), which brings together more than 90 missionary organizations $^{29}$. The diverted money was then used for the 'distribution of basic food baskets 'to vulnerable families" 30 . Although this policy is being expanded due to pressing needs during the pandemic, it is part of a project to impoverish indigenous populations by replacing the right to land with welfare programs (BONILLA and CAPIBERIBE, 2015). Another strange element to this story is the fact that the registered address for the AMTB at the federal revenue service is the same for the ATINI, which was founded by Alves ${ }^{31}$.

The second suggestive story regarding Alves refers to an attempt to reduce the size of the Apyterewa indigenous territory (south of the state of Pará), which has been invaded and deforested at rapid speed since Bolsonaro's inauguration. This story involves the kidnapping of Parakanã leaders by farmers in the region with the support of at least one civil servant from the MMFDH ${ }^{32}$. Alves' response about the case, given on social media, speaks for itself: "We were there to mediate, to end a conflict, to bring peace in order to avoid confrontation. 'And [we did that] at the request of the PF [Federal Police]. You wanted blood from indigenous and agrarian people, is that it?' Does that help promote ideological discourse? Quite frankly..." (Twitter, ALVES, 2020 - emphasis added). It is important to stress that the MMFDH is not legally bound to conduct any type of mediation within indigenous lands.

\footnotetext{
${ }^{29}$ Information is available at <http://www.amtb.org.br/organizacoes-filiadas/>.

${ }^{30}$ Information is available at <https://www1.folha.uol.com.br/poder/2020/09/programa-lideradopor-michelle-bolsonaro-repassa-doacoes-a-ongs-aliadas-de-damares.shtml?origin=uol> .

${ }^{31} \mathrm{~A}$ podcast episode about this case is available at $<$ https:// open.spotify.com/episode/ 02X2nFhYmbc9t5VLLyTOAz?si=DVQ7A8z4RrGQ7QSbqOicBw>.

${ }^{32} \mathrm{An}$ article about this case is available at <https://oglobo.globo.com/sociedade/ministerio-dedamares-intermediou-reuniao-com-fazendeiros-para-pressionar-por-reducao-de-terrademarcada-denunciam-indigenas-24773063>. The public statement from the Parakanã Association is available at <https://racismoambiental.net.br/2020/11/30/carta-associacao-tatoati-apyterewa-povo-parakana/>.
}

$$
\text { (2021) } 15(2) \quad \text { e0003-18/22 }
$$


Ruralists, security forces, and evangelical Christians are now firmly installed in the federal executive. One can say, from an anthropological perspective, that they form correlated terms, that is, they make up a system. The intertwining of these three fronts creates such a complex fabric of schemes and events that it is difficult to fully address it. A summarized elaboration of this strategic, concerted action is provided by a famous character in this charade of dual identities, Edward Mantoanelli Luz, who has deep links with the missionaries and is the most famous of the 'anthropologists of the ruralists'. When celebrating Dias' appointment as coordinator of the division of isolated Indians, Luz explained that Dias's name had been suggested by a group that he "represents, which includes 'sections of the military, Christians (Catholics and Protestants alike), and rural producers affected by the demarcation of indigenous lands'" (TOLEDO, 2020).

\section{Conclusions}

It is in the interest of Bolsonaro's government to ignore the indigenous epistemic-ontological difference - as it was in the case of the Brazilian governments under military rule (1964-1985) - because, on the one hand, this government does not understand this difference, an ignorance that allows them to say that 'the Indians want what we want', that is, 'to be integrated' and follow our methods of land exploitation, to become consumers, Christians, etc. On the other hand, this ignorance could be intentional, as it conveniently downplays the very difference that guarantees the right to indigenous land. Underlying the government's actions towards indigenous people there appears to be a political project that denies indigenous rights and the indigenous existence itself. The depoliticized action of cross-cultural missions - along with the use of theology converges with this political project and contributes to its viability as it instills among indigenous people new customs (such as sedentarism and monogamous marriage) and needs (eating new food items, wearing clothes, and building churches, for instance). These changes tend to reinforce one another and lead the converted indigenous people into a process of increasing economic dependence; they also provide the opportunity for challenging the very need for indigenous land.

When confronted with accusations of intrusion and disrespect for indigenous self-determination due to religious proselytization, cross-cultural missions 
mobilize, in their defense, a notion of freedom based on individualistic values to the detriment of collective rights, a discourse that adds to the military's push for indigenous people's 'integration' into society and to the ruralists' defense of private property. Behind this notion of freedom - which is shared by these actors - is a sense that cultural change is inevitable. In the course of my fieldwork among the Palikur people, I heard this type of reasoning from missionary linguists, expressed as a criticism directed specifically at anthropologists. David Stoll, an American anthropologist who studied SIL in the 1970s, has voiced this critique in the following terms: "[...] translators customarily indict anthropologists for wanting to preserve Indians as cultural specimens, like animals in a zoo, rather than helping them adjust to change as SIL says it does" (STOLL, 1982, p. 16). Any resemblance to President Bolsonaro's rhetoric is not a coincidence.

The sense that individual freedom must surpass collective freedom exposes these missions as emissaries of what Wendy Brown explains to be the result of the 'neoliberal antipolitics' (BROWN, 2019, p. 74). In this case, the freedom to 'accept the word of God' - proposed by missionaries to peoples who are completely unaware of their intentions - directly contradicts the political equality that is essential to democracy, an equality that is legally guaranteed, based on social rights that - if secured by the state - should protect indigenous peoples against the interference from religious, rural, or military groups. By reaching souls, missionary action is undermining indigenous rights. As a consequence, their depoliticized - or anti-political - action exceeds the religious sphere and, paradoxically, turns into an anti-democratic political action.

Translated by Karin Blikstad Submitted on January 21, 2021 Accepted on January 21, 2021

\section{References}

ALMEIDA, Ronaldo de (2006), Tradução e mediação: missões transculturais entre grupos indígenas. In: Deus na Aldeia: missionários, índios e mediação cultural. Edited by MONTERO, Paula. São Paulo: Globo. pp. 277-304.

ALVES, Damares (2020), Matéria enviesada e mentirosa. Publicada sem nem ter nosso lado. Não quis saber. Fomos lá mediar, encerrar um conflito, pacificar com o objetivo de evitar confronto. E a pedido da PF. Queriam 
sangue de indígenas e agrários, é isso? Facilita o discurso ideológico? Francamente. Brasil, 30/11/2020. Twitter, @DamaresAlves. Available at <https://twitter.com/DamaresAlves/status/1333480805969108992>. Accessed on December, 12, 2020.

ANAJURE (2020), Nota pública sobre a ação civil pública movida pelo MPF contra a nomeação do coordenador-geral de índios isolados e de recente contato da Funai. Available at <https://anajure.org.br/anajure-e-fpmlrrah-se-pronunciamsobre-acao-do-mpf-para-suspensao-da-nomeacao-do-antropologo-emissionario-ricardo-lopes-dias-na-funai />. Accessed on November, 28, 2020.

BARROS, Maria Cândida Drumond Mendes (2004), 0 contexto político e intelectual da entrada do Summer Institute of Linguistics na América Latina (1930-1960). Revista Internacional de Lingüística Iberoamericana. Vol. 02, № 04, pp. 149-210.

BEZERRA, André Augusto Salvador (2019), Povos indígenas e Direitos Humanos: direito à multiplicidade ontológica na resistência Tupinambá. São Paulo: Giostri. 164 pp..

BOLSONARO, Jair (2020), Coletiva de imprensa. Dourados. 23/03/2020. Available at <https://www.youtube.com/watch?v=sju-bpj0xE\&ab_channel=BolsonaroTV>. Accessed on November, 28, 2020.

BONILLA, Oiara and CAPIBERIBE, Artionka (2015), Isolados ou cadastrados: os índios na era desenvolvimentista. Revista DR. № 01, pp. 28-33.

BONILLA, Oiara and CAPIBERIBE, Artionka (2021), From flocking for rights to the politics of death: the indigenous struggle and indigenous policy in Brazil (19802020). Portuguese Studies. (in press)

BROWN, Wendy (2019), Nas ruínas do neoliberalismo: a ascensão da política antidemocrática no Ocidente. São Paulo: Editora Filosófica Politéia. 256 pp..

CAPIBERIBE, Artionka (2007), Batismo de fogo: os Palikur e o cristianismo. São Paulo: Annablume. 276 pp..

DIÁRIO DO CONGRESSO NACIONAL (1978), Relatório CPI: Reservas Indígenas. Ano XXXIII, suplemento ao № 72. Brasília: Câmara dos Deputados.

DUPRAT, Débora Macedo (2007), $O$ direito sob o marco $d a$ plurietnicidade/multiculturalidade. Brasília: Ministério Público Federal.

FERNANDES, Rubem César (1980), Um exército de anjos: as razões da Missão Novas Tribos. Religião e Sociedade. № 10, pp. 129-165.

HOLANDA, Marianna Assunção Figueiredo (2018), Os ecos sem voz: uma década de falas sem escuta no Congresso Nacional ainda sobre o 'infanticídio indígena'. Anuário Antropológico. Vol. 43, № I, pp. 155-196. 
JUSTIÇA FEDERAL - SUBSEÇÃO JUDICIÁRIA DE TABATINGA-AM (2020), decisão (ID 219306856) sobre a ação civil pública no 1000314-60.2020.4.01.3201 movida pela UNIVAJA contra os réus Thomas Andrew Tonkin, Josiah Mcintyre, Wilson de Benjamin e Missão Novas Tribos do Brasil. Available at <https://pje1g.trf1.jus.br/pje/DetalheProcessoConsultaPublica/documentoSemL oginHTML.seam?ca=9600d3f9d97298afac66a618d273747ef8742a58d494344ad 486c8369c95429ef0c0fa66b901123dd98f5f787cd7ebae2bd6291faef231e3\&idPr ocessoDoc $=219306856>$. Accessed on November, 26, 2020.

KHEL, Maria Rita (2014), Relatório: violação de Direitos Humanos. Povos Indígenas. Brasília: Comissão Nacional da Verdade.

KOPENAWA, Davi and ALBERT, Bruce (2013), The falling sky: words of a Yanomami Shaman. Cambridge: Belknap Press. 648 pp..

RICARDO, Fany Pantaleoni and GONGORA, Majoí Fávero (eds) (2019), Cercos e resistências: povos indígenas isolados na Amazônia. São Paulo: Instituto Socioambiental. 255 pp..

STOLL, David (1982), Fishers of men or founders of empire? The Wycliffe Bible translators in Latin America. London: Zed Press. 344 pp..

TOLEDO, Diego (2020), Ex-missionário nomeado para FUNAI é acusado de manipular indígenas e dividir aldeias. Available at $<$ https://reporterbrasil.org.br/2020/02/ex-missionario-nomeado-para-funai-eacusado-de-manipular-indigenas-e-dividir-aldeias\%EF\%BB\%BF/>. Accessed on December, 01, 2020.

WETERMAN, Daniel (2018), Por quê manter índios em reserva como se fossem animais em zoólogicos? , diz Bolsonaro. Estadão, Política, 20/ 11/ 2018. Available at <https://politica.estadao.com.br/noticias/geral,por-que-manterindios-em-reservas-como-sefossem-animais-em-zoologicos-dizbolsonaro,70002628617>. Accessed on November, 28, 2020. 